\title{
TEKNIK BUDIDAYA TANAMAN CENGKEH
}

\author{
Sutriyono, Mahrus Ali \\ Fakultas PertanianUniversitas Merdeka Surabaya
}

\begin{abstract}
Abstrak
Cengkeh salah tanaman perkebunan yang dapat dimanfaatkan berbagai keperluan baik sebagai obat maupun keperluan industri yang lainya yang sangat membutuh cengkeh sebagai salah satu bahan baku, maka dari itu untuk mendapat hasil panen cengkeh yang berkualitas perlunya teknik budidaya tanaman cengkeh yang baik dan benar supaya hasil panennya mendapat kualitas yang bagus hargar jual pada cengkeh akan menjadi tinggi sesuai dengan harapan para petani cengkeh.
\end{abstract}

\section{PENDAHULUAN}

Cengkeh adalah tanaman rempah-rempah purbakala yang telah di kenal dan digunakan ribuan tahun sebelum masehi.Pohonnya sendiri merupakan tanaman asli kepulauan Maluku (Ternate dan Tidore),yang dahulu di kenal oleh para penjelajah sebagai spice island.Tanaman cengkeh (Syzigium aromaticum) ini merupakan tanaman perkebunan tropis dengan famili Myrtaceae.Karena iklim tropislah yang menjadi kebutuhan tanaman cengkeh,maka dari itu Indonesia dari dulu hingga sekarang merupakan negara penghasil cengkeh terbesar di dunia dan negara-negara eropa mengimpor cengkeh dari Indonesia(Lestari, 2017).

Cengkeh merupakan tumbuhan yang kaya akan manfaat.Cengkeh juga merupakan rempahrempah wajib dalam berbagai masakan diberbagai daerah di nusantara.Manfaat lain dari cengkeh untuk kesehatan misalnya,untuk mengobati sakit gigi,mencegah radang,anti bakteri dan jamur,meningkatkan kekebalan tubuh,menagani infeksi pernafasan,membersihkan kuman,menyegarkan mulut,melawan kanker,pengusir nyamuk,mengatasi mual dan muntah dll. Budidaya cengkeh saat ini makin dilirik,khususnya oleh kalangan para petani,karena nilai jual yang cukup tinggi kalau dibandingkan dengan rempah-rempah yang lainya,meskipun begitu tidak semua harga cengkeh itu sama.Cengkeh yang mempunyai kualitas bagus pastinya mempunyai nilai jual yang bagus pula (LASTIANTI, 2015).Tapi untuk mendapatkan kualitas cengkeh yang baik,kita harus memahami cara budidaya cengkeh yang baik.

Pada dasarnya langkah budidaya cengkeh tidak terlalu rumit ,tapi untuk hasil yang petani harus memperhatikan beberapa hal agar produksi panen maksimal.Berdasarkan latar belakang di atas maka saya akan mengangkat makalah yang berjudul "BUDIDAYA TANAMAN CENGKEH". Yang mudah-mudahan dapat digunakan sebagai bahan pembelajaran untuk budidaya cengkeh yang dapat meningkatkan kesejahteraan para petani cengkeh(Roesli, Heri, \& Rahayu, 2017). 


\section{KOMODITAS}

Pada abad yang keempat,pemimpin Dinasti Han dari tiongkok memerintahkan setiap orang yang juga dengan perjanjian dengan sultan ternate.Orang portugis membawa banyak cengkeh dari kepulauan maluku ke eropa,pada saat itu harga $1 \mathrm{~kg}$ cengkeh dengan harga 7 gram emas. Perdagangan cengkeh akhirnya didominasi oleh orang belanda pada abad ke-17.Dengan susah payah orang perancis berhasil membudayakn pohon cengkeh di mauritus pada tahn 1770.Akhirnya cengkeh dibudidayakan di Guyana,Brasilia,dan Zanzibar.

Pada abad ke-17 dan ke-18 di inggris harga cengkeh sama dengan harga emas karena tingginya harga emas karena tinnginya biaya impor.Sebab cengkeh disana dijadikan salah satu bahan makanan yang sangat berkhasiat bagi warga dan sekitarnya yang mengkonsumsi tanaman cengkeh tersebut.Sampai sekarang cengkeh mendekatinyauntuk sebelumnya menguyah cengkeh,agar haarum nafasnya.Cengkeh,pala dan merica sangatlah mahal di zaman romawi.Cengkeh menjadi bahan tukar menukar oleh bangsa arab di abad pertengahan.Pada akhir abad ke-15 orang portugis mengambil alih jalan tukar menukar di laut india,bersama itu di ambil alihula perdagangan cengkeh dengan perjanjian tordesillas dengan spanyol,selain itu menjadi salah satu bahan yang diekspor ke luar negeri.

Pohon cengkeh yang dianggap tertua yang masih hidup terdapat di Kelurahan Tongole, Kecamatan Ternate Tengah,sekitar $6 \mathrm{~km}$ dari pusat kota Ternate.Pohon yang disebut sebagai Cengkeh Afo ini berumur 416 tahun, tinggi 36,60m , berdiameter 198m, dan keliling batang 4,26 m.Setiap tahunnya ia mampu menghasilkan sekitar 400kg bunga cengkeh.

\section{KLASIFIKASI DAN MORFOLOGI}

\section{Klasifikasi Tanaman Cengkeh}

Divisi : Spermatophyta

Subdivisi : Angiospermae

Kelas : Dicotyledonae

Bangsa $\quad:$ Myrtales

Suku : Myrtaceae

Marga : Syzygium

Jenis $\quad$ : Syzygium aromaticum (L.) Merr.\& Perry

\section{Morfologi}

\section{Daun}

Daun cengkeh tidak termasuk daun lengkap karena memiliki tangkai daun (petiolus), helaian daun (lamina), namun tidak memiliki upih/pelepah daun (vagina).Daunnya berbentuk berbentuk lonjong dan berbunga pada bagian ujungnya.Termasuk daun majemuk karena dalam satu ibu tangkai ada lebih dari satu daun. 


\section{Batang}

Batang dari pohon cengkeh biasanya memiliki panjang 10 -15 m.Batang berbentuk bulat (teres), permukaan batangnya kasar biasanya memiliki cabang-cabang yang dipenuhi banyak ranting atau dapat dikatakan lebat rantingnya.arah tumbuh batangnya tegak lurus (erectus) dan cara percabangan dari rantingnya dapat dikatakan monopodial karena masih dapat dibedakan antara batang pokok dan cabangnya.Lalu arah tumbuh cabangnya adalah condong ke atas (patens).Selain itu pohon cengkeh dapat bertahan hidup hingga puluhan tahun. Tangkainya kira-kira $1-2,5 \mathrm{~cm}$ (Steenis 1975).

\section{Akar}

Sistem akarnya tunggang,akar ini merupakan akar pokok (berasal dari akar lembaga) yang kemudian bercabang-cabang.Bentuk akar tunggangnya termasuk berbentuk tombak (fusiformis) pada akar tumbuh cabang yang kecil-kecil.Akar kuat sehingga bisa bertahan sampai puluhan bahkan ratusan tahun.Akarnya biasanya mampu masuk cukup dalam ke tanah. Perakaran pohon cengkeh relatif kurang berkembang,tetapi bagian yang dekat permukaan tanah banyak tumbuh bulu akar.Bulu akar tersebut berguna untuk menghisap makanan.

\section{Biji}

Pohon cengkeh mampu menghasilkan biji setelah penanaman 5 tahun.Bijinya terdiri dari kulit (spedodermis), tali pusar (funiculus), dan inti biji (nukleus seminis). Walaupun dalam jangka 20 tahun masih dapat menghasilkan biji, biji ini dapat dikatakan sudah tidak menguntungkan.Hal ini dikarenakan kualitasnya telah menurun dan tidak dapatdigunakan lagi untuk industri, misal rokok.

\section{Bunga}

Bunga cengkeh muncul pada ujung ranting daun (flos terminalis) dengan tangkai pendek dan bertandan (bunga bertangkai nyata duduk pada ibu tangkai bunga).Bunga cengkeh termasuk bunga majemuk yang berbatas karena ujung ibu tangkainya selalu ditutup bunga.Bunga terdiri dari tangkai (pedicellus), ibu tangkai (pedunculus), dan dasar bunga (repectaculum).Bunga cengkeh adalah bunga tunggal (unisexualis) jadi masih dapat dibedakan menjadi bunga jantan (flos masculus) dan betina (flos femineus).Dasar bunganya (repectaculum) menjadi pendukung benang sari dan putik (andoginofor)

\section{Buah}

Cengkeh memiliki tangkai buah yang pada masa awal berwarna hijau dan saat sudah mekar berwarna merah.Buahnya termasuk buah semu karena ada bagian bunga yang ikut ambil bagian dalam pembentukan buah. Buah cengkeh memiliki tangkai buah yang pada masa awal berwarna hijau dan sudah mekar berwarna merah.Buahnya secara umum tersusun atas bagian-bagian secara umum pada kulit buah anatara lain epikarpium, mesokarpium, dan endokarpium.Selain itu ada septum dan ovarium. 


\section{SYARAT TUMBUH}

Untuk dapat tumbuh dan berproduksi dengan baik, tanaman cengkeh memerlukan persyaratan lingkungan tumbuh yang spesifik.Faktor lingkungan yang berpengaruh terhadap tanaman cengkeh antara lain adalah iklim, ketinggian tempat, dan jenis tanah.

\section{Iklim}

Tanaman cengkeh adalah tanaman tropis.Unsur iklim yang cukup menentukan terhadap tingginya produktivitas tanaman cengkeh adalah curah hujan.Curah hujan yang optimal untuk perkembangan tanaman cengkeh adalah 1500 - $2500 \mathrm{~mm} / \mathrm{tahun}$ atau $2500-3500 \mathrm{~mm} / \mathrm{tahun}$.Iklim dan pembungaan tanaman mempunyai hubungan yang saling berkaitan karena untuk keluarnya bunga diperlukan suatu hormon yang pembentukannya dirangsang oleh faktor iklim.Untuk keluarnya bunga pada tanaman cengkeh diperlukan musim yang agak kering tanpa hujan sama sekali dan penyinaran matahari yang agak terik.Bila keadaan iklim ini tidak mendukung, maka bunga baru akan keluar pada ranting-ranting yang sekurang-kurangnya telah mengalami dua masa pertumbuhan vegetative setelah pembungaan yang terakhir.

\section{Ketinggian Tempat}

Tanaman cengkeh dapat dibudidayakan di dataran rendah sampai dataran tinggi, namun akan lebih produktif apabila di tanam di dataran rendah.Tanaman ini masih dapat berproduksi pada ketinggian tempat 0 - $900 \mathrm{~m}$ di atas permukaan laut (dpl).Namun demikian makin tinggi tempat maka produksi bunga makin rendah, tetapi pertumbuhan makin subur.Ketinggian tempat yang optimal untuk pembungaan tanaman cengkeh berkisar $200-600 \mathrm{~m}$ dpl.

\section{Tanah}

Tanah yang sesuai adalah tanah yang gembur, lapisan olah minimal 1,5 m dan kedalaman air tanah lebih dari $3 \mathrm{~m}$ dari permukaan tanah serta tidak ada lapisan kedap air.Jenis tanah yang cocok antara lain andosol, latosol, regosol, dan podsolikmerah.Selain jenis tanah, keasaman tanah ( $\mathrm{pH}$ ) ikut berperan dalam hal memacu pertumbuhan tanaman.Keasaman tanah yang optimum berkisar antara 5,5 - 6,5.Apabila $\mathrm{pH}$ tanah lebih rendah atau lebih tinggi maka pertumbuhan tanaman cengkeh akan terganggu karena penyerapan unsur hara oleh akar menjadi terhambat.

\section{PEMBAHASAN}

\section{TEKNIK BUDIDAYA TANAMAN CENGKEH}

\section{Persemaian dan Pembibitan}

Proses budidaya cengkeh biasanya dimulai dari kerja pembibitan dan persemaian.Agar bisa memperoleh dan menghasilakan pohon cengkeh yang produktif dan berkualitas, maka kerja pembibitan dan persemaian harus dilakukan secara baik, cermat dan teliti. Dalam memilih tempat persemaian, ada beberapa faktor yang diperhatikan : 
1. Tanah harus subur dan mudah diairi (terutama pada musim kemarau)

2. Tempat persemaian harus terlindungi dari angin kencang

3. Tempat strategis (misalnya mudah mengangkut benih dan dekat dengan areal tanam)

Tahap-tahap kerja yang harus dilakukan dalam persemaian:

1. Membuat patok atau tanda pada tanah yang akan dicangkul.Lebarnya maksimal $175 \mathrm{~cm}$ dan panjangnya maksimal $5 \mathrm{~m}$, atau ditentukan secara kondisional dengan cara melihat lahan atau medan.

2. Diantara bedengan persemaiandiberi parit air kira-kira $50 \mathrm{~cm}$.

3. Pencangkulan tanah yang akan dibuat bedengan sedalam kira-kira $30 \mathrm{~cm}$.

4. Membersihkan rerumputan dan tanaman pengganggu lainnya hingga ke akar-akarnya.

5. Pencangkulan diulangi 3 kali untuk menggemburkan tanah, kemudian digulut kira-kira 20 $\mathrm{cm}$ di atas permukaan parit.

6. Sekeliling tiap gulutan/bedengan persemaian diberi penahan (amping) supaya tanah persemaian tidak larut kena air.

7. Tanah dicampur dengan pupuk kandang yang telah masak rata-rata 1 blek tiap $3 \mathrm{~m}^{2}$ atau kondisional, melihat intensitas kesuburan tanah.

8. Memasang peneduh setinggi rata-rata 2 meter dengan atap alang-alang, daun kelapa atau jerami.

9. Tiap-tiap gulutan/bedengan disemprot dengan insektisida atau dicampur bubuk incex untuk membunuh ulat tanah,gangsir,rayap, dan lain-lain, yang senang memakan bibit cengkeh.

Setelah semuanya siap, biji mulai ditanam.Pilihlah biji kualitas terbaik atau unggul.Biji bisa disediakan sendiri jika mempunyai induk tanaman cengkeh yang bagus.Jika tidak punya benih yang bagus, sebaiknya mencari di toko-toko pertanian dan tanaman yang terpercaya. Jika benih dari biji akan dipindahkan pada umur 1 tahun, maka jarak tanamnya 20x20 cm.Jika benih dari biji akan dipindahkan pada umur 2 tahun, maka jarak tanamnya 30x30 cm. Sebaiknya biji dikecambahkan dulu, kurang lebih selama 5 hari sehingga pertumbuhan akarnya lurus dan baik.Caranya, biji ditempatkan pada keranjang-keranjang pipih yang diberi tanah secukupnya.Biji cengkeh ditaruh berjajar rata pada tempat tersebut.

Jika sudah berkecambah, maka biji dibawa ke persemaian, dicabuti satu-satu dan ditanam persis pada leher akarnya.Dengan cara ini, batang dan akar cengkeh akan tumbuh lurus sehingga memudahkan penanaman di areal kelak. plastic Jika tidak ada hujan hingga 2 - 3 hari berturut-turut, maka benih harus cepat disiram dengan alat penyiram yang lubangnya halus, agar biji-biji tidak terpelanting. Pada umur 3 bulan, tanah-tanah sekitar bibit-bibit tadi digemburkan dengan solet (bamboo selebar 2 jari yang ditipiskan).Selain itu, rerumputan dan tanaman pengganggu harus dicabuti agar tidak merampas gizi-gizi dalam tanah yang menjadi jatah makanan benih cengkeh.Penggemburan tanah sekaligus disertai pemberian pupuk urea dengan dosis \pm 30 gram per $\mathrm{m}^{2}$.Penggemburan tanah dan pemupukan dengan cara yang sama dilakukan tiap satu bulan sekali. 
Jika benih telah berumur empat bulan maka peneduh mulai dijarangkan, sehingga pada umur satu tahun peneduh buatan sudah bisa dibuka, supaya benih mendapat sinar matahari yang banyak.Karena semakin banyak sinar matahari akan berpengaruh pada percabangan menjadi baik dan sehat. Bibit bisa dipelihara hingga $1-2$ tahun, dan penggunaan bibit yang berumur 2 tahun akan lebih baik pada pertumbuhannya.Pengambilan bibit harus hati-hati jangan sampai akarnya rusak. Cara pengambilan benih harus hati-hati, usahakan pengambilan benih dengan tanahnya supaya akar tidak rusak, kemudian tanah yang didalamnya akar dapat dibungkus dengan dan gedebog pisang yang telah dikeringkan, atau dengan pembungkus lain, yang paling penting tanah dan akar tidak pecah.

Setelah benih dibungkus, taruh benih ditempat yang teduh selama $1-2$ minggu, selama bibit disimpan sebaiknya disemprot dengan K.O.C $1-2 \%$ untuk menahan pertumbuhan jamur pada daun.Akan lebih baik lagi kalau disemprot dengan insektisida.

\section{Persiapan Lahan}

Dalam mempersiapkan lahan, yang harus dilakukan adalah:

1. Pembersihan lahan (bekas tunggak atau akar kayu yang dapat menyebabkan rayap atau jamur akar) yang kemudian dilanjutkan dengan pengolahan tanah.

2. Pembuatan lubang tanam yang biasanya disiapkan sejak bulan Juli sampai dengan September dan ditutup pada bulan Oktober, tujuannya agar lubang dan tanah galiannya terkena panas yang cukup lama.Ukuran (panjang,lebar dan kedalaman) yang biasa digunakan dalam pembuatan lubang tanam yaitu : (i) 60x60x60 cm, (ii) 80x80x80 cm, dan (iii) $1 \times 1 \times 1 \mathrm{~m}$.

3. Pada 2 minggu sampai 1 bulan sebelum tanam, tanah diberi pupuk kandang yang telah menjadi tanah atau kompos sebanyak $5-10 \mathrm{~kg} /$ pohon.

4. Untuk mengatur kelebihan air perlu dibuat saluran drainase yang cukup.

\section{Penanaman}

Penanaman dilakukan apabila semua persiapannya, misalnya teras ering telah baik, peneduh alam atau buatan telah siap, lubang-lubang tanam yang memenuhi syarat telah ditutup kembali, serta jarak tanam telah ditentukan. Jarak tanaman yang biasa digunakan pada penanaman cengkeh tidak sama tergantung pada ketinggian dan kemiringan tanah.Jarak tanam pada tanah datar $8 \mathrm{~m} \times 8 \mathrm{~m}=156$ pohon dan pada tanah agak miring minimal $6 \mathrm{~m} \times 6 \mathrm{~m}=256$ pohon, atau dapat dibuat bervariasi $8 \mathrm{~m}$ x $6 \mathrm{~m}=200$ pohon, $6 \mathrm{~m} \times 7 \mathrm{~m}=238$ pohon, $7 \mathrm{~m} \mathrm{x} 8 \mathrm{~m}=178$ pohon.Bila terdapat gangguangangguan yang dapat merugikan, jarak tanam dapat dibuat lebih rapat lagi, misalnya $4 \mathrm{~m} \mathrm{x} 4 \mathrm{~m}=625$ pohon.

Penanaman cengkeh dilaksanakan pada awal musim hujan.Dalam penanamannya dilakukan pula pola tanam campuran (polikultur) dengan sistem tanam pagar, yaitu memperkecil jarak tanam dalam baris (Timur - Barat) misalnya $12 \mathrm{~m}$ x $5 \mathrm{~m}$ atau $14 \mathrm{~m}$ x $6 \mathrm{~m}$ sehingga tersedia ruangan untuk tanaman sela atau tanaman campuran.Tanaman campuran dapat dilakukan pada tanaman yang belum 
produktif dan atau kurang produktif.Beberapa tanaman campuran yang dapat digunakan antara lain: kacang tanah, kacang tunggak, jagung, dan tanaman lain kecuali ketela pohon karena ketela pohon menyerap banyak garam-garam mineral dari dalam tanah dan tidak dikembalikan sehingga sangat cepat mengurangi kesuburan tanah.

\section{PEMUPUKAN DAN PEMELIHARAAN}

Setelah bibit cengkeh ditanam ke lapangan tahap selanjutnya adalah pemeliharaan.Pada tanaman cengkeh, pemeliharaan merupakan periode yang panjang, yaitu selama tanaman yang diusahakan tersebut dianggap masih menguntungkan secara ekonomis

\section{Pengelolaan Lahan dan Tanaman}

Penggemburan Tanah dan Sanitasi Kebun.

a. Tanaman cengkeh yang berumur $1-5$ tahun merupakan periode kritis, sekitar $10-30 \%$ tanaman yang telah ditanam di lapangan mengalami kematian atau perlu diganti /disulam karena berbagai sebab, seperti hama penyakit, kekeringan, kalah bersaing dengan gulma, atau penyebab lainnya.

b. Penggemburan tanah disekeliling tanaman di daerah sekitar perakaran di cangkul dangkal $( \pm$ $10 \mathrm{~cm}$ ) sekurang-kurangnya 2 kali setahun, pada awal dan akhir musim hujan sekaligus sebagai persiapan pemupukan

c. Gulma atau alang - alang harus dibersihkan sampai akar - akarnya dengan cangkul / garpu atau dengan penyemprotan herbisida.

\section{Pengaturan Naungan}

a. Pada stadia awal pertumbuhan, tanaman cengkeh memerlukan naungan yang cukup.Ada dua naungan yang digunakan, yaitu:

a) Naungan buatan / sementara

Dapat menggunakan daun nyiur yang dianyam, atau kepang dari bamboo hingga umur 2 tahun.

b) Naungan alami

Sekitar tanaman di kanan / kiri dan di belakang sebaiknya ditanami dengan pupuk hijau.Maksudnya untuk menahan teriknya sinar matahari, menahan angin dan mematahkan jatuhnya hujan yang lebat.Pohon peneduh yang ditanam biasanya Theoprocia, Flumingia, Congesta, yang bukan merupakan saingan akar

b. Naungan buatan diadakan maksimal untuk dua periode musim kemarau setelah penanaman.

c. Bila naungan alami (pohon peneduh) sudah terlihat gelap harus segera dipangkas, pangkasan dimasukkan ke dalam rorak (sebagai humus). Jangan memangkas pada musimkemarau karena akan merugikan.

d. Setelah tanaman cengkeh mencapai umur 5 tahun naungan alami (pohon peneduh) sama sekali dihilangkan, karena tanaman sudah tahan terhadap semua pengaruh dari luar.

\section{Penyulaman}


a. Waktu penyulaman sebaiknya dilakukan pada musim hujan, yaitu untuk menghindari kematian tanaman karena kekurangan air

b. Bibit sulaman yang digunakan berasal dari sumber benih dan umur yang tidak jauh berbeda dengan tanaman yang telah ditanam.

\section{Penyiraman}

a. Pada awal pertumbuhan, tanaman cengkeh memerlukan kondisi tanah yang lembab, sehingga pada musim kemarau perlu adanya penyiraman.Setidak - tidaknya penyiraman dilakukan $2-3$ kali sehari.Penyiraman dilakukan pada sore hari setelah pukul 15.00 karena saat sore hari keadaannya sejuk dan tidak akan terjadi penguapan yang banyak sehingga air dapat diserap oleh akar dalam jumlah yang banyak

b. Pada tanaman dewasa penyiraman kurang diperlukan lagi, kecuali pada kondisi iklim ekstrim kering.

\section{Pemasangan Mulsa}

Pemasangan Mulsa dilakukan menjelang musim kemarau.Tujuannya untuk menjaga kelembaban tanah disekitar tanaman dan memberikan kondisi yang lebih baik bagi pertumbuhan akar.

\section{Pemupukan}

Pemupukan bertujuan untuk memperbaiki pertumbuhan tanaman dan meningkatkan produksi cengkeh setelah panen.Berdasarkan pola penyebaran akarnya, penempatan pupuk pada tanaman cengkeh dilakukan dibawah proyeksi tajuk dan bagian dalam tajuk(Ali, 2015).

Pemupukan diberikan 2 kali dalam setahun, yaitu saat awal musim hujan (akhir musim kemarau) dan saat awal musim kemarau (akhir musim hujan).Jenis pupuk yang diberikan dapat berupa pupuk organik (pupuk kandang atau kompos) dan pupuk anorganik, baik tunggal maupun berupa pupuk majemuk dalam bentuk butiran maupun tablet.

Pupuk organic berbentuk butiran (UREA, TSP/SP-36, KCI, Kieserit) diberikan pada proyeksi tajuk $2 / 3$ bagian dan $1 / 3$ bagian dibawah bagian dalam tajuk yang dilakukan dua kali setahun, yaitu pada awal dan akhir musim hujan.Pupuk anorganik berbentuk tablet, diberikan dalam 8 lubang tugal (4 lubang di bawah proyeksi tajuk daun 4 lubang dibawah tajuk bagian dalam) sedalam $10-15 \mathrm{~cm}$, pupuk tablet hanya setahun sekali, yaitu pada awal musim hujan.

\section{HAMA DAN PENYAKIT}

\section{Kutu Daun ( Coccus viridis)}

Bagian yang diserang : ranting muda,daun muda.Gejala : Pertumbuhan yang dihisapnya akan terhenti misal ranting mengering,daun dan bunga kering dan rontok.Pencegahangunakan PENTANA + AERO - 810 atau Natural BVR

2. Penggerek Ranting/Batang (Xyleborus sp) 
Bagian yang diserang : ranting/batang.Gejala : Liang gerekan berupa lubang kecil,serangan hebat menyebabkan ranting/batang menjadi rapuh dan mudah patah.Pengendalian : Pangkas ranting/batang yang terserang,pencegahan gunakan PESTONA atau Natural BVR

3. Kepik Helopeltis (Helopeltis sp)

Bagian yang diserang : pucuk atau daun muda.Gejala : Biasanya pucuk akan mati dan daun muda berguguran.Pencegahan : Semprotkan Natural BVR atau PESTONA.

4. Penyakit mati bujang (bakteri Xylemlimited bacterium)

Bagian yang diserang : perakaran,ranting-ranting muda.Gejala : matinya ranting pada ujungujung tanaman.Gugurnya daun diikuti dengan matinya ranting secara bersamaan.Pengendalian:pengaturan drainase yang baik,penggemburan tanah,pencegahan kocorkan POC NASA + HORMONIK + NATURAL GLIO

5. Penyakit busuk akar (Pytium rhizoctonia dan Phytopthora)

Bagian yang diserang perakaran.Gejala : pada pembibitan tanaman mati secara tiba-tiba, pada tanaman dewasa daun mengering mulai dari ranting bagian bawah.Pengendalian : bila serangan telah ganas maka tanaman yang terserang dibongkar dan dimusnahkan, lubang bekas tanaman berikan tepung belerang $200 \mathrm{gr}$ secara merata, isolasi tanaman atau daerah yang terserang dengan membuat saluran isolasi, perbaiki drainase, gunakan Natural GLIO pada awal penanaman untuk pencegahan.

\section{PANEN DAN PASCA PANEN}

\section{PEMANENAN}

Produk utama cengkeh adalah bunga, yang pada waktu dipanen kadar airnya berkisar antara $60-70 \%$.Waktu yang paling baik untuk memetik cengkeh adalah sekitar 6 bulan setelah bakal bunga timbul, yaitu setelah satu atau dua bunga pada tandannya mekar dan warna bunga menjadi kuning kemerah-merahan dengan kepala bunga masih tertutup, berisi dan mengkilat.

Pemungutan bunga cengkeh dilakukan dengan cara memetik tangkai bunga dengan tangan, kemudian dimasukkan ke dalam kantong kain atau keranjang yang telah disiapkan, menggunakan tangga segitiga atau galah dari bamboo, serta tidak merusak daun disekitarnya saat pemetikan.waktu panen sangat berpengaruh terhadap rendemen dan mutu bunga cengkeh serta minyak atsirinya.

Saat pemetikan bunga cengkeh yang tepat yaitu apabila bunga sudah penuh benar tetapi belum mekar, pemetikan yang dilakukan saat bunga cengkeh masih muda (sebelum bunga masak) akan menghasilkan bunga cengkeh yang kering yang keriput, kandungan minyak atsirinya rendah dan berbau langu (tidak enak).Sedangkan apabila pemetikannya lambat 9 bunga sudah mekar setelah dikeringkan akan diperoleh mutu yang rendah, tanpa kepala serta rendemennya rendah(Ali, 2017).

\section{PASCA PANEN}

Sebelum dikeringkan, bunga cengkeh dipisahkan dari tangkai atau gagang dan dikeringkan secara terpisah.Pada tahap ini dilakukan pemisahan antara bunga cengkeh yang baik, bunga yang 
terlalu tua dan yang terjatuh, setelah itu bunga cengkeh dikeringkan. Pengeringan dapat dilakukan dengan menjemurnya di bawah sinar matahari langsung atau menggunakan pengering buatan.Bunga cengkeh yang akan dijemur dihamparkan pada alas tikar,anyaman bamboo gribig, atau plastik, atau pada lantai jemur yang diberi alas plastic.Selama proses pengeringan, cengkeh dibolak balik agar keringnya merata.proses pengeringan dianggap selesai apabila warna bunga cengkeh telah berubah menjadi coklat kemerahan,mengkilat, mudah dipatahkan dengan jari tangan dan kadar air telah mencapai sekitar 10 - $12 \%$.Lamanya waktu penjemuran dibawah sinar mataharisekitar 3 - 4 hari.Cengkeh yang telah kering kalau disimpan tidak akan susut beratnya dan tahan lama asalkan tidak terkena air.

Kualitas cengkeh dapat dibedakan dan dinilai menurut:
a. Kekeringannya
b. Persentase kotoran (tangkai bunga dan daun-daun)
c. Persentase yang tidak berkepala (sudah banyak yang mekar)
d. Persentase yang muda
e. Warnanya

\section{KESIMPULAN}

Cengkeh merupakan tanaman rempah-rempah asli indonesia yang berasal dari pulau Maluku.pohon cengkeh dapat tumbuh baik didaerah yang memiliki iklim tropis,maka dengan iklim yang sangat mendukung ini,Indonesia menjadi negara penghasil cengkeh terbesar nomor 1 didunia, sehingga negara-negara eropa banyak yang mengimpor cengkeh dari Indonesia.pohon cengkeh juga dikenal sebagai tanaman rempah-rempah dan obat tradisional dengan banyak manfaat.

\section{REFERENCES}

Bambang, S. 1999. Mari Menanam Cengkeh. PD Nasional. Surabaya

Departemen Pertanian. 2007. Prospek dan Arah Pengembangan Agribisnis Cengkeh.

Departemen Pertanian, Jakarta

Ali, M. (2015). PENGARUH DOSIS PEMUPUKAN NPK TERHADAP PRODUKSI DAN

KANDUNGAN CAPSAICIN PADA BUAH TANAMAN CABE RAWIT (Capsicum frutescens

L.). JURNAL AGROSAINS: KARYA KREATIF DAN INOVATIF, 2(2), 171-178.

Ali, M. (2017). TEKNIK BUDIDAYA TANAMAN PERKEBUNAN TANAMAN TEMBAKAU.

LASTIANTI, S. D. D. (2015). KAJIAN MANAJEMEN RISIKO SEBAGAI UPAYA UNTUK

MENCAPAI KEBERHASILAN PADA PROYEK KONSTRUKSI BAJA DAN SIPIL DI PT

SUPRA SURYA INDONESIA. UNIVERSITAS AIRLANGGA.

Lestari, V. N. S. (2017). PENTINGNYA MOTIVASI DALAM UPAYA MENINGKATKAN 
PRODUKTIVITAS KARYAWAN.

Roesli, M., Heri, A., \& Rahayu, S. (2017). Authority of Land Procurement Committee In The Implementation of Compensation For Land Acquisition. YURISDIKSI: Jurnal Wacana Hukum Dan Sains, 10(2), 46-59.

Deptan. 2010. Teknologi Unggulan Tanaman Cengkeh Pusat Penelitian dan Pengembangan

Direktorat Jenderal Perkebunan. 2012.Pedoman Teknis Rehabilitasi Tanaman Cengkeh. Kementerian Pertanian, Jakarta

Muhandas, R.W., D.A. Setyawati., S. Ernitawati., P. Widyaningrum., N. D. Faradila. Mahasiswa n Fakultas Pertanian, Universitas Gadjah Mada, Yogyakarta

AAK. 1973. Bagaimana Menanam Cengkeh. Kanisius. Yogyakarta.

Perkebunan.http://balittri.litbang.go.id/database/unggulan/bookletcengkeh. Diakses pada tanggal 16 November 2015.

Sihotang, B. 2008. Andaliman. http://bens.co/budidayatanaman/andaliman. Diakse 16 November 2015. 